\title{
Enzymes as Biocatalysts: Review on Investigations on Synthesis, Mechanism, Kinetics, Applications and Potential
}

\author{
Sunil Kulkarni 1 ,*iD \\ 1 Gharda Institute of Technology, Lavel, Maharashtra, India \\ * Correspondence: suniljayantkulkarni@gmail.com;
}

Scopus Author ID 57209247314

Received: 15.02.2021; Revised: 10.05.2021; Accepted: 20.05.2021; Published: 27.06.2021

\begin{abstract}
Sustainable development is becoming the goal of many investigations carried out in chemistry and chemical engineering. Because of the waste generated by chemical reactions, there is a shift from traditional thinking about the catalyst's yield, selectivity, efficiency, and effectiveness. Mild, low temperature, highly selective alternative was found in biological reactions. Biocatalyst application fulfills the two important requirements. It does not deplete natural resources and does not have any significant environmental footprints. Modeling of biological reactions is a very important area of investigation on enzyme-catalyzed reactions. Monod and Moser growth kinetics can be applied to cell growth and substrate utilization. The discovery of new enzymes and optimization of the synthesis and application methods for biocatalysts are being investigated widely for better and industrially applicable technologies.
\end{abstract}

Keywords: yield; selectivity; kinetics; catalysis; sustainable development; resources.

(C) 2021 by the authors. This article is an open-access article distributed under the terms and conditions of the Creative Commons Attribution (CC BY) license (https://creativecommons.org/licenses/by/4.0/).

\section{Introduction}

Cells are the basic building blocks of our bodies. Cells can utilize enzymes. The enzymes have amazing catalytic power and high specificity [1]. Side reactions and by-products are rarely produced in biological or enzyme-catalyzed reactions [2]. The quantity of enzymes required is very small compared to the substrates, and they remain completely unchanged in the reaction [3]. Michalis Menten Kinetic equations form the basis for many investigations on enzyme kinetics [4]. Sustainable development is becoming the goal of many investigations carried out in chemistry and chemical engineering [5]. Because of the waste generated by chemical reactions, there was a shift from traditional thinking about the catalyst's yield, selectivity, efficiency, and effectiveness [6,7]. Mild, low temperature, highly selective alternative was found in biological reactions. The biocatalyst application fulfills the two important requirements. It does not deplete natural resources and does not have significant environmental footprints $[8,9]$. Many biological methods can synthesize many products, such as single-cell proteins, ethanol, vinegar, glucose, amino, and lactic acids [10-20]. Modeling of biological reactions is a very important area of investigation on enzyme-catalyzed ]reactions[21]. Monod and Moser growth kinetics can be applied to cell growth and substrate utilization $[22,23]$. Many times, it becomes necessary to form a new model based on the mechanism of adsorption [24]. Bacterial growth kinetics can also provide insight into 
biochemical reactions [25]. Better results can be obtained by investigating various sources of carbon [26].

\section{Biocatalysts: Advantages and Uses}

Biocatalysts can be used for many fermentation, reduction, decomposition, and other reactions [26-31]. The production of chiral 2-hydroxyalkylphosphonate esters can be carried out by reducing cyanobacteria as biocatalysts [26]. Optically pure phosphonates can be synthesized by biochemical enzymatic reactions [27]. Biocatalyst processes are accepted widely in pharmaceutical and fine chemical synthesis. High specificity is an advantage in these applications. Proper design and control strategy is a very important aspect of biocatalyst synthesis and applications as these biocatalysts are very sensitive [28]. Biocatalysts are very effective in stereoselective applications, also [29]. Aspects such as limited commercial availability, thermal instability, limited range of substrates, and poor stereoselectivity put limitations on the application of biocatalysts for such applications [30]. The discovery of new enzymes and optimization of biocatalysts' synthesis and application methods is investigated widely for better and industrially applied technology [31]. Different techniques of enzyme immobilization have also been studied by various investigators for studying effectivity [3236].

\section{Investigations on Enzyme Synthesis by Efficient Pathways}

Research work on green synthesis and enzyme kinetics is summarized in Tables 1 and 2 , respectively. Proteins carry out a variety of functions like transport, storage, support, and antibodies. Proteins also act as an enzyme in many reactions. For enzyme or biocatalyst, selectivity and volume efficiency are very important properties [37]. For the synthesis of glycosides, enzymatic pathways offer a better option by overcoming the limitations of the chemical synthesis method. Immobilization by a suitable method such as adsorption can be very effective for efficiently using enzymes in biochemical reactions. Adamczak and Krishna investigated the improvement of enzymes for efficient biocatalysts [38]. Bio-catalysis has a wide scope in the pharmaceutical and agrochemical industries. Excellent results are obtained by the application of gene encoding for enzymes. Improvement in the activation methods and microbial screening has resulted in novel enzymes resulting in new biocatalysts pathways for different properties. Barbosa et al. investigated lipase immobilization [39]. They used Mesoporous silica as support for the biocatalyst. They observed that when modified by the protic ionic liquid, the yield and operational stability increased. According to this investigation, lipase immobilized into silica aerogel by encapsulation methods showed the best immobilization technique.

Enzyme deactivation or a dramatic drop-in catalytic activity may occur because of the use of organic solvents and harsh operating conditions [40]. Detailed molecular understanding and study can help to address such limitations. It is possible to finetune the catalyst by modifying the solvent, the support, or the enzyme's active site. DNA recombination can be used to enhance the catalytic properties of the enzyme. The biocatalyst system should be reusable for an effective process. So, in addition to stability and active nature, reusability is an important aspect of biocatalyst [40]. Preparation of magnetic biocatalyst is also reported [41]. Magnetically assisted bioprocesses can improve the production of biodiesel. Neumann et al. investigated surface properties and energetic properties of Pseudomonas putida in a two-phase 
fermentation process [42]. They used the organic solvent 1-decanol(10\%) as the medium. Their investigation measured the cell surface hydrophobicity and charged in the presence and absence of 1-decanol. Growth rate and growth yield were affected due to $\mathrm{n}$ the presence of 1decanol.

In the synthesis of various products by biochemical and enzymatic pathways, modernization and sophistication of the processes are important aspects [43]. For the production of many products such as biofuel, waste materials and by-products can be utilized as starting materials. Bio-catalysis is an environmentally friendly process. Such processes are a strategic choice in the modern economy than the only green alternative. These processes are environmentally friendly and safer. Crude liquid residues such as molasses, glycerine, and cassava residues can be used in submerged fermentation. Solid residues can be used as a cheaper culture media for solid-state fermentation [43]. Biocatalysts are very useful in effluent treatment also. Selective removal of compounds in effluent treatment can be facilitated by using a suitable biocatalyst. According to Chapman et al., a multidisciplinary approach is required to develop immobilized biocatalysts [44]. They emphasized that enzyme immobilization can improve industrial processes. Catalysis can be improved in terms of activity and stability across a broader range of operating conditions by applying the immobilization technique. Immobilization techniques like carrier-bound attachment, encapsulation or entrapment, and the formation of cross-linked enzyme aggregates can increase the yield and selectivity. Smith et al. discussed the cell surface display method for novel and improved biocatalysts [45]. Many limitations in enzyme purification and substrate transport can be overcome by the surface display method.

Table 1. Research for enzymes for green synthesis.

\begin{tabular}{|c|c|c|}
\hline Sr.No. & Authors & Details \\
\hline$[4]$ & Johnson, K. A.; Goody, R. S. & $\begin{array}{l}\text { The authors translated the original Michaelis and } \\
\text { Menten paper. In doing so, they observed that Michaelis } \\
\text { and Menten analyzed initial velocity measurements and } \\
\text { fit their full-time course data to the integrated form of } \\
\text { the rate equations. }\end{array}$ \\
\hline$[5]$ & Sheldon, R.A.; Woodley, J.M. & $\begin{array}{l}\text { The authors revealed that it is possible to develop } \\
\text { enzyme transformations that can fit the predefined } \\
\text { parameters, making it truly useful for sustainable design. }\end{array}$ \\
\hline [6] & Sheldon, R. A. & $\begin{array}{l}\text { The author discussed the fundamentals of green and } \\
\text { sustainable chemistry principles in the context of organic } \\
\text { synthesis. }\end{array}$ \\
\hline [7] & Sheldon, R. A. & $\begin{array}{l}\text { The author discussed the role of green chemistry in } \\
\text { organic synthesis. }\end{array}$ \\
\hline$[8]$ & Graedel, T. E. & $\begin{array}{l}\text { The author emphasized the importance of sustainable } \\
\text { methods for the synthesis of organic compounds. }\end{array}$ \\
\hline [9] & Oxford University Press & $\begin{array}{l}\text { A report was prepared by the World Commission on } \\
\text { Environment and Development about environmental } \\
\text { decay, poverty, and hardship; also about the depletion of } \\
\text { resources and increasing pollution. }\end{array}$ \\
\hline$[10]$ & Kulkarni, S.J. & $\begin{array}{l}\text { The author discussed the increasingly important role of } \\
\text { biotechnology in synthesizing various fine chemicals, } \\
\text { drugs, intermediates, and compounds. }\end{array}$ \\
\hline$[11]$ & Kulkarni, S.J. & $\begin{array}{l}\text { The author discussed the role of enzyme production of } \\
\text { citric acid. According to him, Citric acid can be } \\
\text { manufactured using various raw materials such as fruit } \\
\text { peel, molasses, and other waste feedstock. He discussed } \\
\text { literature on the use of various feedstocks such as } \\
\text { molasses, fruit peel waste, corncob, and other waste } \\
\text { material with appropriate enzymes. }\end{array}$ \\
\hline$[12]$ & $\begin{array}{l}\text { Ramachandran, V.; Nisha Pujari, N.; Tanmay Matey, } \\
\text { T.; Kulkarni, S. }\end{array}$ & $\begin{array}{l}\text { The authors explored different sources of amylase } \\
\text { enzymes like rice, maize, sorghum, and wheat and } \\
\text { analyzed optimum germination and subsequent } \\
\text { hydrolysis conditions. }\end{array}$ \\
\hline
\end{tabular}




\begin{tabular}{|c|c|c|}
\hline Sr.No. & Authors & Details \\
\hline [13] & $\begin{array}{l}\text { Ramachandran, V.; Pujari, N.; Matey, T.; Kulkarni, } \\
\text { S. }\end{array}$ & $\begin{array}{l}\text { The authors studied enzymatic hydrolysis of cassava } \\
\text { using wheat seedlings. They investigated the effects of } \\
\text { various parameters on the quality of glucose syrup. }\end{array}$ \\
\hline [14] & Kulkarni, S.J. & $\begin{array}{l}\text { The author highlighted the role of enzyme technology in } \\
\text { the synthesis of various products from various waste } \\
\text { feedstocks. }\end{array}$ \\
\hline [15] & Kulkarni, S.J.; Shinde, N.L.; Goswami A.K. & $\begin{array}{l}\text { Ethanol production from agricultural waste raw } \\
\text { materials like potato waste, molasses, banana waste, } \\
\text { waste food grain, etc., was discussed. The review } \\
\text { highlighted that enzymatic hydrolysis is the most potent } \\
\text { alternative process for saccharification of complex } \\
\text { polymer. }\end{array}$ \\
\hline [16] & Bekmuradov, V. & $\begin{array}{l}\text { The author investigated standard and modified cellulose } \\
\text { organic-solvent-based lignocellulosic fractionation for } \\
\text { source-separated organic waste. The modified method } \\
\text { was } 20 \text { percent more effective. }\end{array}$ \\
\hline [19] & Wadhwa, M.; Bakshi, M.P.S. & $\begin{array}{l}\text { The authors pointed out that the key to the development } \\
\text { of sustainable feedstock lies in the use of readily } \\
\text { available feedstock and the development of sustainable } \\
\text { processes with minimum waste generation. }\end{array}$ \\
\hline [20] & $\begin{array}{l}\text { Vishwakarma, H.S.; Kumar, A.; Singh, J.; Dwivedi, } \\
\text { S.; Kumar, M. }\end{array}$ & $\begin{array}{l}\text { Ethanol was synthesized from fruit wastes by using } \\
\text { Saccharomyces Cerevisiae. Optimum temperature and } \\
\mathrm{pH} \text { were observed to be } 32^{\circ} \mathrm{C} \text { and } 5.5 \text {, respectively. }\end{array}$ \\
\hline [21] & Kulkarni, S.J. & $\begin{array}{l}\text { The author discussed the modeling of biological } \\
\text { reactions. He discussed investigations on enzyme } \\
\text { kinetics. Kinetics of substrate utilization and cell growth } \\
\text { can be modeled by Moser and Monod like kinetic } \\
\text { equations. }\end{array}$ \\
\hline [31] & Robertson, D.E.; Steer, B.A & $\begin{array}{l}\text { According to the authors, enantiomerically pure fine } \\
\text { chemicals and the movement away from chemically } \\
\text { burdened technologies are driving factors for the rapid } \\
\text { acceptance of enzyme-catalyzed processes. }\end{array}$ \\
\hline [40] & Osbon, Y.; Kumar, M. & $\begin{array}{l}\text { The authors discussed enzyme improvement } \\
\text { technologies and highlighted their limitations and } \\
\text { advantages in real-world technological applications. }\end{array}$ \\
\hline [41] & $\begin{array}{l}\text { Rodrigues, P.M.; David, G.F.; } \text { Ferreira, P.R.; } \\
\text { Delatorre, A.B.; Teixeira, V.F.T.; } \text { Cubides, D.C.; } \\
\text { Pereira, N.C.;Perez, V.H }\end{array}$ & $\begin{array}{l}\text { The authors discussed the synthesis and application of } \\
\text { biocatalysts with magnetic properties. }\end{array}$ \\
\hline [42] & $\begin{array}{l}\text { Neumann, G.; Cornelissen, S.; van Breukelen, F.; } \\
\text { Hunger, S.; Lippold, H.; Loffhagen, N.; Wick, L.Y.; } \\
\text { Heipieper, H.J. }\end{array}$ & $\begin{array}{l}\text { The investigation established that putida DOT-T1E as } \\
\text { the biocatalyst and 1-decanol as the solvent is a stable } \\
\text { system for two-phase biotransformations }\end{array}$ \\
\hline [124] & $\begin{array}{l}\text { Jeandet, P.; Sobarzo-Sánchez, E.; Silva, A.S.S.; } \\
\text { Clément; Nabavi, A.F; Battino, M., C.; Nabavi, A.F; } \\
\text { Battino, M.; Rasekhian, M.; Belwal, T.; } \\
\text { Habtemariam, S.; Koffas, M.; Nabavi, S.M. }\end{array}$ & $\begin{array}{l}\text { The authors examined various approaches for the } \\
\text { synthesis of potential pharmacological resveratrol } \\
\text { derivatives }\end{array}$ \\
\hline
\end{tabular}

Table 2. Research on enzyme kinetics.

\begin{tabular}{l|l|l} 
Sr.No. & Authors & Details \\
\hline$[23]$ & Liu , Z.; Li, X. & $\begin{array}{l}\text { The authors established a new model for the kinetics of } \\
\text { ethanol fermentation. }\end{array}$ \\
\hline$[24]$ & Van Den Wijngaard, A.; Richele, W.; Dick, J. & $\begin{array}{l}\text { In this investigation, the kinetics of bacterial growth on } \\
\text { chlorinated aliphatic compounds was studied. It was } \\
\text { found that chlorinated compound removal efficiency } \\
\text { was influenced by the first catabolic enzyme's kinetic } \\
\text { properties and cellular content. }\end{array}$ \\
\hline$[25]$ & Muthuvelayudham, R.; Viruthagiri, T. & $\begin{array}{l}\text { Fermentative production and kinetics of cellulase } \\
\text { protein on Trichoderma reesei were studied for various } \\
\text { carbon resources. Maximum enzyme activity was } \\
\text { observed on cellulose with lactose and bagasse with } \\
\text { xylose. }\end{array}$ \\
\hline$[26]$ & Monika Gorak, M.; Żymańczyk-Duda, E. & $\begin{array}{l}\text { Investigators used autotrophic microorganisms as a } \\
\text { biocatalyst for the reduction of oxoalkylphosphonates. }\end{array}$ \\
\hline$[27]$ & Rodak, M.B. & $\begin{array}{l}\text { A wide range of enzymatic activities was observed } \\
\text { towards a number of non-physiological substrates. }\end{array}$ \\
\hline$[28]$ & Kaushik, N.; Biswas, S.; Singh, J. & $\begin{array}{l}\text { The authors discussed aspects like scope and types of } \\
\text { biocatalysts, their application, reuse, screening technics. }\end{array}$ \\
\hline$[29]$ & Kulkarni S J & $\begin{array}{l}\text { The author has summarized research on the analysis and } \\
\text { properties of oxalic acid. Also, its synthesis from low- }\end{array}$
\end{tabular}




\begin{tabular}{l|l|l}
\hline Sr.No. & Authors & Details \\
\hline$[30]$ & $\begin{array}{l}\text { Kinfe, H.H.; Chhiba, V.P.; Frederick, J.; Mathiba, } \\
\text { K.; Brady, D. }\end{array}$ & $\begin{array}{l}\text { cost feedstocks, removal from water, and its different } \\
\text { applications were discussed. }\end{array}$ \\
\hline $\begin{array}{l}\text { Applications of stereoselective biocatalysts for the } \\
\text { enantiomeric resolution of beta-hydroxy nitriles were } \\
\text { investigated. }\end{array}$ \\
\hline$[43]$ & $\begin{array}{l}\text { Ferreira-Leitão, V.S.F.; Cammarota, M.C.; } \\
\text { Aguieiras, E.C.G.; Vasconcelos de Sá, L.R.; } \\
\text { Fernandez-Lafuente, R.; Freire, D.M.G. }\end{array}$ & $\begin{array}{l}\text { The utilization of renewable resources for enzymatic } \\
\text { processes was discussed. The role of enzymatic } \\
\text { processes to support sustainability was also highlighted. }\end{array}$ \\
\hline [47] & Contois, D.E. & $\begin{array}{l}\text { The relationship between population density and the } \\
\text { specific growth rate of continuous cultures was } \\
\text { discussed for the bacterial growth kinetics. }\end{array}$ \\
\hline [48] & Olaoye O.S.; Kolawole O.S. & $\begin{array}{l}\text { Anon-structured model was applied to the kinetics of } \\
\text { ethanol formation from glucose biomass in batch } \\
\text { culture. }\end{array}$ \\
\hline [50] & Pao, G.V.R.S.; Murty, K.S.; Nagendra B. D. & $\begin{array}{l}\text { A fluidized bed bioreactor was used for COD and BOD } \\
\text { removal from domestic sewage. The kinetics of removal } \\
\text { was studied. }\end{array}$ \\
\hline
\end{tabular}

\section{Biocatalysts: Enzyme Kinetics and Substrate Utilization}

Many investigations on enzymes are focused on kinetics, as listed in Table 2. The oxygen uptake rate method was studied by Toretta et al. [46]. They studied biological kinetics in a conventional municipal wastewater treatment plant [46]. In their investigation, they observed that the kinetic parameters were in agreement with the literature ranges. The kinetics of bacterial growth was investigated by Contois [47]. He studied the effect of population density upon specific growth rates of bacterial populations. Olaoye and Kolawole [48] investigated ethanol formation from glucose biomass in batch culture. Their investigation indicated that the Logistics model and Gompertz model described experimental data. They neglected the inhibitory effects of the substrate. Rao et al. used a fluidized bed bioreactor to remove biological oxygen demand, BOD, and chemical oxygen demand, COD [49]. According to this investigation, the bio-kinetic reactions taking place in the reactor confirm the first-order rate of equations. Prakash and Sochan treated tannery wastewater [50]. They investigated biotransformation reactions during anaerobic decomposition. They observed that the BOD reduction could be increased by proper maintenance of the required alkalinity.

\section{Some Advanced Investigations on Enzymes}

In the synthesis of antibacterial agents, heterogeneous biocatalysts were investigated by Afridi et al. [51]. They synthesized a superparamagnetic folic acid-coated nanocomposite as a catalyst. Many investigations have reported on magnetite-supported catalysis [52,53]. Synthesis of nanoparticles and nanomaterials has also been reported by using biocatalysis [54]. As biological methods are environmentally friendly and sustainable, attempts are being made to synthesize nanomaterials by biological methods $[55,56]$. Enzyme inhibitors affect enzyme activity. Investigations on enzyme inhibitors are a very important part of biocatalyst studies [57-59]. Tables 3 and 4 provide a summary of studies and investigations on immobilization and inhibition, respectively.

Many investigations are carried out on the preparation, analysts, and effect of enzymes on biological reactions and exploring the possibility of replacing chemical pathways with enzymatic ones [60, 61]. However, according to Dua, the validity of Michaelis-Menten (MM) expression is limited to macroscopic amounts of enzymes and substrates [62]. 
Table 3. Investigations on Enzyme Immobilization.

\begin{tabular}{|c|c|c|}
\hline Sr.No. & Authors & Details \\
\hline$[17]$ & $\begin{array}{l}\text { Petre, M.; Zarnea, G.; Adrian, P.; } \\
\text { Gheorghiu, E. }\end{array}$ & $\begin{array}{l}\text { Biodegradation of cellulose wastes was carried out using bacterial } \\
\text { and fungal cells immobilized in radiopolymerized hydrogels. The } \\
\text { study emphasized the importance of the physical structure and } \\
\text { chemical properties of such polymeric matrices used to preserve } \\
\text { their metabolic activity. }\end{array}$ \\
\hline [32] & Kulkarni, S.J. & $\begin{array}{l}\text { Various methods of enzyme immobilization were discussed, and } \\
\text { investigations on enzyme immobilization were summarized by } \\
\text { the author. }\end{array}$ \\
\hline [33] & Kulkarni, S.J. & $\begin{array}{l}\text { Synthesis of vinegar from various feedstocks was discussed. The } \\
\text { role of enzymatic processes was underlined in the production of } \\
\text { vinegar-like products. }\end{array}$ \\
\hline$[34]$ & Nawani, N.; Singh, R.; Kaur, J. & $\begin{array}{l}\text { An investigation was carried out on immobilization and stability } \\
\text { studies of a lipase from thermophilic Bacillus sp. Various } \\
\text { methods to increase thermostability were applied and compared. }\end{array}$ \\
\hline$[35]$ & Ding, L.; Yao, Z.; Li, T.; Yue, Q.; Chai, J. & $\begin{array}{l}\text { The authors investigated papain immobilization on a } \\
\text { macroporous polymer carrier.it was observed that the } \\
\text { immobilized papain by this method had higher activity recovery, } \\
\text { remarkable stability, better reusability, and environmental } \\
\text { adaptability }\end{array}$ \\
\hline [36] & $\begin{array}{l}\text { Abdelmajeed, N.A.; Khelil O.A.; Danial, } \\
\text { E.N. }\end{array}$ & $\begin{array}{l}\text { Investigators discussed various methods for immobilization for } \\
\text { enhancing the bio-products industry. It was reiterated that } \\
\text { immobilization technologies are very useful in bi-product } \\
\text { synthesis. }\end{array}$ \\
\hline [37] & $\begin{array}{l}\text { Nair V.K.; More M.K.; Sawant J.J.; } \\
\text { Thikekar V.P.;, Philip P.A.;Ojha M.D.; } \\
\text { Gomase V.S. }\end{array}$ & $\begin{array}{l}\text { The use of proteins as biocatalysts and biomaterials was } \\
\text { discussed. The authors also discussed the discovery and } \\
\text { development of extremophilic enzymes and industrial enzymes. }\end{array}$ \\
\hline$[38]$ & Adamczak, M.; Krishna, S.H. & $\begin{array}{l}\text { The gene encoding a particular enzyme was found to yield } \\
\text { excellent results. }\end{array}$ \\
\hline [39] & $\begin{array}{l}\text { Barbosaa, A.S.; Lisboaa, J.A.; Silvaa, } \\
\text { M.A.O.; Carvalhoa, N.B.; Pereirab, M.M.; } \\
\text { Fricksa, A.T.; Mattedid, S.; Limaa, A.S.; } \\
\text { Franceschic, E.; Soaresa, C.M.F. }\end{array}$ & $\begin{array}{l}\text { Silica aerogel modified with protic ionic liquid was investigated } \\
\text { for lipase immobilization and found to be suitable. }\end{array}$ \\
\hline$[86]$ & Bashir, N.; Sood, M.; Bandral, J. & $\begin{array}{l}\text { The authors discussed enzyme immobilization for its applications } \\
\text { in food processing. The authors emphasized the need to overcome } \\
\text { the current limitations related to immobilization techniques. }\end{array}$ \\
\hline [87] & Labus, K.; Wolanin, K.; Radosinski, L. & $\begin{array}{l}\text { Invertase immobilization was investigated using alginate and } \\
\text { gelatin. }\end{array}$ \\
\hline [88] & $\begin{array}{l}\text { Chou, C.; Syu, S.; Chang, J.H.; Aimar, P.; } \\
\text { Chang, Y. }\end{array}$ & $\begin{array}{l}\text { Bioinspired pseudo-zwitterionic hydrogels with bioactive enzyme } \\
\text { immobilization via ph-responsive regulation were studied. It was } \\
\text { observed that pH-responsive adsorption holds the potential for } \\
\text { designing a biocompatible tissue engineering matrix. }\end{array}$ \\
\hline [89] & Bao, Z.; Xian, C.; Yuan, Q.; Liu, G.; Wu, J. & $\begin{array}{l}\text { The authors summarized work on the progress of natural polymer- } \\
\text { based hydrogels with enhanced mechanical properties. }\end{array}$ \\
\hline [90] & Basso, A.; Serban, S & $\begin{array}{l}\text { Industrial applications of immobilized enzymes were discussed } \\
\text { by the authors. }\end{array}$ \\
\hline [91] & $\begin{array}{l}\text { Bilal, M.; Zhao, Y.; Noreen, S.; Shah, } \\
\text { S.Z.H.; Bharagava, R.N.; Iqbal, H.M.N. }\end{array}$ & $\begin{array}{l}\text { According to the authors, physical or covalent coupling and cross- } \\
\text { linked enzyme crystals are the most promising methods for } \\
\text { immobilization. }\end{array}$ \\
\hline [92] & Liu, Q.; Xun, G.; Feng, Y. & $\begin{array}{l}\text { The state-of-the-art strategies of protein engineering for enzyme } \\
\text { stabilization were discussed. The authors highlighted practical } \\
\text { cases to show the importance of enzyme stabilization. }\end{array}$ \\
\hline
\end{tabular}

Cellulase was produced in submerged fermentation by Legodi et al. [63], for these fungi, was isolated from the natural compost. Cellulase is becoming an increasingly important enzyme in the biofuel industry [64]. Yeast can be used for deriving thermostable cellulase [65]. Research work on applications of cellulase, amylases are tabulated in Table 5. Cellulase enzymes can be produced from bacteria and yeast. Cellulase obtained from yeast is active in a wide range of $\mathrm{pH}$, hence, gaining importance. These are capable of producing cellulase at high temperatures $\left(60-70^{\circ} \mathrm{C}\right)[66,67]$. Enzymes in human beings, animals, and parasitic organisms have been well established [68]. Pectinase is one of the important enzymes used for the degradation of pectic substances. They are used in the food industry, especially fruit juice 
clarification [69-71]. Investigations on reductase, pectinase are listed in table 6. Many investigators have studied the characteristics of pectine and various production methods. Pectinase has contributed significantly to the pharmaceutical sector, also [72-74].

Amylases are used for the hydrolysis of starch. Alpha-amylase helps in the prevention and medical treatment of metabolic syndromes [75]. Many molecules have $\alpha$-amylase inhibitory activity [76-78]. In green plants, alpha-amylase genes are being investigated and evolved [79]. Bhattacharjee et al. have discussed the different types of bacterial and fungal amylases and their various applications in industries [80]. They discussed alpha and beta amylases and their applications. They discussed applications of amylases in food, bakery, brewing, detergent, textile, and paper industries.

According to Timson, four major challenges for better biocatalysts are protein folding understanding, a qualitative understanding of the hydrophobic effect, understanding and quantification of the effects of organic solvents on biomolecules, and understanding of enzymatic catalysis [81]. Nevertheless, many attempts are being made to improve biocatalysts. For example, in ester formations, lipases are now used with success $[82,83]$.

Biocatalysts are becoming increasingly important in the pharmaceutical industry [84]. The use of various enzyme routes to obtain products such as aldehydes has been reported [85]. The immobilization of the enzyme helps in retaining catalyst activity [86]. Higher turnover over a considerable period can be achieved due to immobilization. Hydrogel matrices can be used for enzyme immobilization [87-89]. Many investigations on hydrogel enzymes are focused on studying mechanical properties and enhancing those, synthesis, a study of structures and properties [89-91]. The selection of enzymes in immobilized form can be made by evaluating costs versus benefits obtained in the process [89-91]. According to Liu et al., combining computational enzyme design with molecular evolution will hold considerable promise in this field [92].

Enzymes are used in food processing since ancient times [93]. Modern microbial enzymes are more stable than food or plant enzymes [94]. Enzymes such as amylases, glucoamylases, proteases, lactases, lipases, phospholipases, lipoxygenases, cellulases, xylanases, etc., are used widely in the food industry [95-97]. Various approaches, including molecular and biochemical methods, can be used for the modification of microbial enzymes. Many investigations on microbial enzymes are reported in Table 7. Attributes like environmentally friendly nature, efficient process control, high yield, low refining costs, and process safety makes them the attractive choice for the synthesis of various products.

Enzymes are playing a key role in modern agricultural developments. Soil enzymes work as bioindicators for soil quality and its health [98-100]. Biological equilibrium, soil quality changes, and properties can be monitored by using the soil enzymes as indicators. The use of different fertilizers to improve productivity may alter enzyme activities over a period of time [101]. Many applications of enzymes and their role in agriculture are being explored by many investigators, as indicated in Table 8. Soil extracellular enzymes are agents for the creation and decomposition of organic material. Technological advancement may sometimes have an adverse effect on biodiversity, including soil enzyme activities [102]. Factors such as favorable soil $\mathrm{pH}$, a higher content of organic $\mathrm{C}$, and a total $\mathrm{N}$ and $\mathrm{C} / \mathrm{N}$ ratio can positively affect the activity of enzymes in the organic system [103]. Biofilms formed by pathogenic bacteria can be dealt with by various nonconventional methods based on bacteriocins, bacteriophages, disruptive enzymes, essential oils, nanoemulsions, and nanoparticles, and the use of alternative technologies [104]. Disruptive methods can be used for the efficient release 
of enzymes [105]. Investigations are reported on various methods for increasing the enzyme activities and effective enzyme release [106-110]. Enzymes play a vital role in the technological developments in other agriculture-based small-scale industries such as dairy, fishery, poultry farms, and food industries [111-118]. From ancient times enzymes are used for beverage manufacturing. Investigations for improving the enzymatic processes' economy are being carried out, and novel technics are being explored [119-124]. Investigations on inhibitory effects, substrate utilization, enzyme kinetics, synthesis of thermostable enzymes indicate that there is still a lot of potential in biotechnology and enzyme technology for intensifying many processes and finding economical methods for the synthesis of various products.

Table 4. Investigations on inhibition.

\begin{tabular}{l|l|l} 
Sr.No. & Authors & Details \\
\hline$[57]$ & Kacar, D.; Baltaci, A.K.; Ayar, A.; Mogulkoc, R. & $\begin{array}{l}\text { The authors investigated the effects of different } \\
\text { phosphodiesterase type 5 enzyme inhibitors on the } \\
\text { isolated rat myometrium contraction. It was found } \\
\text { that tadalafil inhibits the frequency, amplitude, and } \\
\text { area under the contraction curve. }\end{array}$ \\
\hline$[58]$ & Ayar A., & $\begin{array}{l}\text { This investigation predicted that parecoxib could be } \\
\text { of therapeutic use in the management of preterm } \\
\text { labor and dysmenorrhoea. }\end{array}$ \\
\hline$[59]$ & $\begin{array}{l}\text { Nagiub, M., Filippone, S., Durrant, D., Das, A., } \\
\text { Kukreja, R.C. }\end{array}$ & $\begin{array}{l}\text { The authors proposed that tadalafil can be used for } \\
\text { improving cardiac function in survivors of } \\
\text { childhood cancer. }\end{array}$ \\
\hline [60] & $\begin{array}{l}\text { Lauro, F.V.; Francisco, D.C.; Marcela, R.N.; Virginia, } \\
\text { M.A.; Patricia, H.V.; Laura, B.C.; Pool Gómez, E.; } \\
\text { Lenin, H.H.; Maria, L.R.; Regina, C.C., et al. }\end{array}$ & $\begin{array}{l}\text { Three steroid derivatives were synthesized, and } \\
\text { their activities were evaluated. }\end{array}$
\end{tabular}

Table 5. Applications of cellulase, amylases.

\begin{tabular}{|c|c|c|}
\hline Sr.No. & Authors & Details \\
\hline [63] & $\begin{array}{l}\text { Legodi, L.M.; La Grange, D.; Rensburg E.L.J.; } \\
\text { Ncube, I. }\end{array}$ & $\begin{array}{l}\text { In this investigation, the authors isolated fungi from } \\
\text { natural compost and produce cellulases in } \\
\text { submerged fermentation. }\end{array}$ \\
\hline [64] & $\begin{array}{l}\text { Zhuang, J.; Marchant, M.A.; Nokes, S.E.; Strobel, } \\
\text { H.J. }\end{array}$ & $\begin{array}{l}\text { The authors concluded that solid-state cultivation } \\
\text { might increase the potential of bioethanol to } \\
\text { become a viable supplemental fuel source. }\end{array}$ \\
\hline [65] & $\begin{array}{l}\text { Touijer, H.; Benchemsi, N.; Ettayebi, M.; Idrissi, } \\
\text { A.J.; Chaouni, B.; Bekkari, H. }\end{array}$ & $\begin{array}{l}\text { Yeast-derived cellulases could hydrolyze soluble } \\
\text { and insoluble substrates at elevated temperatures } \\
\text { and at a wide } \mathrm{pH} \text { range. }\end{array}$ \\
\hline [66] & Xu, Z; Cen, Y; Zou, S; Xue, Y; Zheng, Y. & $\begin{array}{l}\text { The authors discussed recent advances in the } \\
\text { improvement of enzyme thermostability by } \\
\text { structure modification. Protein structure } \\
\text { modification can improve thermostability. }\end{array}$ \\
\hline [67] & $\begin{array}{l}\text { Megha, S.V.; Maragathavalli, S.; Brindha, S.; } \\
\text { Karthikeyan, V.; Annadurai, B.; Gangwar, S.K. }\end{array}$ & $\begin{array}{l}\text { The authors discussed the isolation and purification } \\
\text { of cellulase. According to these studies, enzyme } \\
\text { activities were at their best at } \mathrm{pH} 4-7 \text { and the } \\
\text { temperatures between } 40^{\circ} \mathrm{C} \text { to } 50^{\circ} \mathrm{C} \text {. }\end{array}$ \\
\hline [68] & Prast-Nielsen, S.; Huang, H.H.; Williams, D.L. & $\begin{array}{l}\text { The role of Thioredoxin glutathione reductase in } \\
\text { redox and its potential as a target for drugs was } \\
\text { investigated. Thioredoxin glutathione reductase } \\
\text { plays a vital role in the redox biology of } \\
\text { parasitic flatworms. }\end{array}$ \\
\hline [95] & Aiyer, P.V. & $\begin{array}{l}\text { The author discussed applications of amylases in } \\
\text { various fields. }\end{array}$ \\
\hline [122] & $\begin{array}{l}\text { Ogasawara, M.; Yoshii, K.; Wada, J.; Yamamoto, Y.; } \\
\text { Inouye, K }\end{array}$ & $\begin{array}{l}\text { The authors identified guanine, guanosine, and } \\
\text { inosine for } \alpha \text {-amylase inhibitors in the extracts of } \\
\text { the earthworm Eisenia fetida. Also, they } \\
\text { characterized their inhibitory activities against } \\
\text { porcine pancreatic } \alpha \text {-amylase. }\end{array}$ \\
\hline
\end{tabular}


Table 6. Applications of reductase, pectinase.

\begin{tabular}{|c|c|c|}
\hline Sr.No. & Authors & Details \\
\hline [69] & Agorio, A.; Chalar, C.; Cardozo, S.; Salinas, G. & $\begin{array}{l}\text { The authors investigated alternative mRNAs arising } \\
\text { from trans-splicing code for mitochondrial and } \\
\text { cytosolic variants of Echinococcus granulosus } \\
\text { thioredoxin glutathione reductase. }\end{array}$ \\
\hline [70] & Rendón , J.L.; Miranda-Leyva, M.M. & $\begin{array}{l}\text { Thioredoxin-Glutathione Reductase (TGR) enzyme } \\
\text { follows a two-site ping-pong bi kinetic mechanism }\end{array}$ \\
\hline [71] & $\begin{array}{l}\text { Roy, K.; Dey, S.; Uddin, M.K.; Barua, R.; Hossain, } \\
\text { M.T. }\end{array}$ & $\begin{array}{l}\text { Bacterial isolates were isolated from the vegetable } \\
\text { dump waste soil. It was observed that the pectinase } \\
\text { of the isolate has potentiality on different types of } \\
\text { fruit juice clarification. }\end{array}$ \\
\hline$[72]$ & $\begin{array}{l}\text { Satapathy, S.; Rout, J.R.; George Kerry, G.; Thatoi, } \\
\text { H.; Sahoo, S.L. }\end{array}$ & $\begin{array}{l}\text { In this article, the authors described various } \\
\text { production methods related to the optimization of } \\
\text { the product. They also highlighted the significant } \\
\text { contribution of pectinase to the pharmaceutical. }\end{array}$ \\
\hline [73] & Nigam, P.S. & $\begin{array}{l}\text { The author highlighted special characteristics like } \\
\text { thermotolerance and } \mathrm{pH} \text { tolerance. He observed that } \\
\text { the enzyme activity was not affected by } \mathrm{pH} \text { and } \\
\text { temperature over a wide range of these parameters. }\end{array}$ \\
\hline [74] & $\begin{array}{l}\text { Wilkowska, A; Nowak, A; Antczak-Chrobot, A; } \\
\text { Motyl, I; Czyzowska, A; Paliwoda, A. }\end{array}$ & $\begin{array}{l}\text { Investigators carried out our research to identify the } \\
\text { composition and biological activity of pectin- } \\
\text { derived oligosaccharides (POS) generated from } \\
\text { mild acid or enzymatic hydrolysis of apple pomace } \\
\text { (AP). }\end{array}$ \\
\hline$[76]$ & $\begin{array}{l}\text { Kato, C.C.; Gonçalves, G.D.A.; Peralta, R.A.; } \\
\text { Seixas, F.A.V.; Sá-Nakanishi, A.B. ; 1,2 Lívia } \\
\text { Bracht, L.; Comar, J.F.; Bracht, A.; Peralta, R.M. }\end{array}$ & $\begin{array}{l}\text { Investigations were done on inhibition of } \alpha \text { - } \\
\text { Amylases by condensed and hydrolyzable tannins. } \\
\text { Kinetics and hypoglycemic actions were studied in } \\
\text { detail. }\end{array}$ \\
\hline [77] & Kumari, N.; Sushil, Rani, B.; Malik K.; Avtar, R. & $\begin{array}{l}\text { The authors discussed recent advancements in } \\
\text { microbial amylases. }\end{array}$ \\
\hline [78] & Martina, M.F.; Okpob, E.A.; Andyc, I.E. & $\begin{array}{l}\text { The authors discussed alpha-amylase, beta- } \\
\text { amylase, and glucoamylase and their unique way of } \\
\text { action. }\end{array}$ \\
\hline [79] & $\begin{array}{l}\text { Liangliang, J.; Zhifen, P.; Haili Zhang H.; Qiao L.; } \\
\text { Junjun, L.;, Guangbing, D.; Maoqun,Y.; Hai, L. }\end{array}$ & $\begin{array}{l}\text { The authors discussed the origin and evolution of } \alpha \text { - } \\
\text { amylase genes in green plants in detail. }\end{array}$ \\
\hline [80] & Bhattacharjee, I.; Mazumdar, D.; Saha, S.P. & $\begin{array}{l}\text { The authors discussed microbial amylases and their } \\
\text { potential application in industries, highlighting the } \\
\text { role of these compounds in green synthesis. }\end{array}$ \\
\hline [81] & Timson, D.J. & $\begin{array}{l}\text { According to the author, four challenges for better } \\
\text { biocatalysts are understanding protein folding, a } \\
\text { qualitative understanding of the hydrophobic effect, } \\
\text { studying the effects of organic solvents on } \\
\text { biomolecules, and understanding enzymatic } \\
\text { catalysis. }\end{array}$ \\
\hline$[82]$ & $\begin{array}{l}\text { Yang, Y.; Zhang, J.; Wu, D.; Xing, Z.; Zhou, Y.; Shi, } \\
\text { W.; Li, Q. }\end{array}$ & $\begin{array}{l}\text { Lipases were employed as a catalyst for the } \\
\text { chemoenzymatic synthesis of polymeric materials. }\end{array}$ \\
\hline$[83]$ & Kumar, A.; Dhar, K.; Kanwar, S.S.; Arora, P.K. & $\begin{array}{l}\text { The advantages of lipase-catalyzed reactions in } \\
\text { organic solvents were highlighted. Also, various } \\
\text { effects of organic solvents on their activity were } \\
\text { summarized. }\end{array}$ \\
\hline$[84]$ & Zhang, M.M.; Su,X.; Ang, E.L.; Zhao, H. & $\begin{array}{l}\text { The authors discussed the strategic application of } \\
\text { the tools like recombinant DNA technology, protein } \\
\text { engineering, and bioinformatics. }\end{array}$ \\
\hline$[85]$ & $\begin{array}{l}\text { Lee, J.; Kim, J.;Kim, H.; Kim, E J.; Jeong, H.; Choi, } \\
\text { K.; Kim, B. }\end{array}$ & $\begin{array}{l}\text { Investigators characterized Tryptophan 6- } \\
\text { Halogenase from Streptomyces albus. Also, they } \\
\text { studied its Regioselectivity Determinants. }\end{array}$ \\
\hline [95] & Aiyer, P.V. & $\begin{array}{l}\text { The author discussed applications of amylases in } \\
\text { various fields. }\end{array}$ \\
\hline
\end{tabular}

Table 7. Microbial enzymes

\begin{tabular}{l|l|l} 
Sr.No. & Authors & Details \\
\hline$[93]$ & $\begin{array}{l}\text { Raveendran, S.; Parameswaran, B.; Ummalyma, } \\
\text { S.B.; Abraham, A.; Mathew, A.K.; Madhavan, A.; } \\
\text { Rebello, A.; Pandey, A. }\end{array}$ & $\begin{array}{l}\text { Easy, cost-effective, and consistent production is } \\
\text { advantages of the application of microbial enzymes } \\
\text { in food preparations. }\end{array}$ \\
\hline$[94]$ & Rodríguez Couto S, Ángeles Sanromán M. & $\begin{array}{l}\text { Solid-state fermentation is becoming an alternative } \\
\text { to submerged fermentation in specific applications } \\
\text { because of advancements in reactor design. }\end{array}$
\end{tabular}




\begin{tabular}{l|l|l}
\hline Sr.No. & Authors & Details \\
\hline$[100]$ & Rozylol, K.; Bohacz, J. & $\begin{array}{l}\text { The microbial activity of the subsoil can be } \\
\text { improved by using biogas digestate and mineral } \\
\text { mining waste. }\end{array}$ \\
\hline$[101]$ & $\begin{array}{l}\text { Holík, L.; Hlisnikovsky, L.; Honzík, R.; Trogl, J.; } \\
\text { Hana .B.; Popelka, J. }\end{array}$ & $\begin{array}{l}\text { This investigation indicated that the use of } \\
\text { combined fertilization might improve biological } \\
\text { characteristics in deeper parts of the soil profile. }\end{array}$ \\
\hline$[105]$ & $\begin{array}{l}\text { Costa-Silva, T.A; Flores-Santos, J.C.; Freire, R.K.B.; } \\
\text { Michele Vitolo, M.; Pessoa-Jr, A. }\end{array}$ & $\begin{array}{l}\text { Microbial cell disruption methods for efficient } \\
\text { release of enzyme L-asparaginase were studies. The } \\
\text { studies indicated that the mechanical methods were } \\
\text { the } \\
\text { microbst effective for the disintegration of all }\end{array}$
\end{tabular}

Table 8. Enzymes in agriculture.

\begin{tabular}{|c|c|c|}
\hline Sr.No. & Authors & Details \\
\hline [98] & Yuvaraj, M.; Ramasamy, M. & $\begin{array}{l}\text { The authors discussed the role of fungi in } \\
\text { agriculture. The role of fungi in changing root } \\
\text { morphology, absorption of nutrients, nutrient } \\
\text { mobility were discussed. }\end{array}$ \\
\hline [99] & Gunjal, A.; Waghmode, M.; Patil, N.; Nawani, N. & $\begin{array}{l}\text { The authors emphasized the significance of soil } \\
\text { enzymes in agriculture. Soil enzymes are indicators } \\
\text { of soil quality and fertility. }\end{array}$ \\
\hline [102] & Catherine T.; Tony S. & $\begin{array}{l}\text { It was predicted that the animal agricultural system } \\
\text { would be replaced by food as a software model. In } \\
\text { this, foods will be engineered at a molecular level. }\end{array}$ \\
\hline [103] & $\begin{array}{l}\text { Cezary A. K.; Elzbieta H.; Feledyn-Szewczyk, B.; } \\
\text { Antonkiewicz, J. }\end{array}$ & $\begin{array}{l}\text { The activity of enzymes was correlated with } \\
\text { favorable soil } \mathrm{pH} \text {, a higher content of organic } \mathrm{C} \text {, and } \\
\text { total } \mathrm{N} \text {, and } \mathrm{C} / \mathrm{N} \text { ratio }\end{array}$ \\
\hline [104] & $\begin{array}{l}\text { Grigore-Gurgu,L.; Bucur, F. I.; Borda, D.; Alexa, } \\
\text { E.; Neagu C.; Nicolau, A. }\end{array}$ & $\begin{array}{l}\text { The authors discussed the ability of some } \\
\text { pathogenic and toxigenic bacteria to form biofilms. } \\
\text { Also, their contribution to the persistence of these } \\
\text { microorganisms in the food industry was } \\
\text { highlighted. }\end{array}$ \\
\hline [112] & Dekker, P.J.T.; Koenders, D.; Bruins, M.J.; & $\begin{array}{l}\text { The authors discussed the market developments and } \\
\text { production possibilities and issues of lactose-free } \\
\text { dairy products. }\end{array}$ \\
\hline [113] & Bezie, A.; Regasa, H. & $\begin{array}{l}\text { The authors reviewed the application of starter } \\
\text { culture and enzymes/ rennet for fermented dairy } \\
\text { products. }\end{array}$ \\
\hline [114] & Attia, Y.A. & $\begin{array}{l}\text { The authors discussed the use of enzymes in poultry } \\
\text { diets. }\end{array}$ \\
\hline [115] & $\begin{array}{l}\text { Selim, N.A.; Magied, H.A.A.; Habib, H.H.; Waly, } \\
\text { A.H.; Fadl, A.A.; Shalash, S.M. }\end{array}$ & $\begin{array}{l}\text { According to the authors, protease and xylanase } \\
\text { Enzymes can be employed as single or combined } \\
\text { supplementation to corn-soybean meal broiler diets. }\end{array}$ \\
\hline [116] & $\begin{array}{l}\text { Barisic, V.; Kopjar, M.; Jozinovic , A.; Flanjak, I.; } \\
\text { Ackar, D.; Milicevic, B.; Subaric, D.; Jokic, S.; } \\
\text { Babic, J. }\end{array}$ & $\begin{array}{l}\text { The authors discussed the chemistry behind } \\
\text { chocolate production. They highlighted important } \\
\text { reactions involving proteins, carbohydrates, lipids, } \\
\text { and polyphenols. }\end{array}$ \\
\hline [117] & $\begin{array}{l}\text { Urbanska, B.; } \quad \text { Derewiaka, D.; Lenart, A.; } \\
\text { Kowalska, J. }\end{array}$ & $\begin{array}{l}\text { The authors studied the changes in the composition } \\
\text { and content of polyphenols in chocolate. These } \\
\text { changes result from the pre-treatment method } \\
\text { of cocoa beans and the technological process. The } \\
\text { data collected by authors can be helpful for the } \\
\text { processes which require further studies and } \\
\text { analyses. }\end{array}$ \\
\hline [118] & de Brito, E.S.; García, N.H.P.; Amancio, A.C. & $\begin{array}{l}\text { It was observed that a product formulated with } \\
\text { protease-treated cocoa had an enhanced perception } \\
\text { of chocolate flavor and bitter taste. }\end{array}$ \\
\hline [120] & Sibel Uzuner, S.; Deniz Cekmecelioglu, D. & $\begin{array}{l}\text { The authors discussed enzymes used in the } \\
\text { beverage industry. Typically, pectinases, amylases, } \\
\text { cellulases, and xylanases are used to extract and } \\
\text { clarify fruit juices. Pectinase holds } 25 \text { percent of the } \\
\text { share of food enzymes globally. }\end{array}$ \\
\hline
\end{tabular}




\section{Conclusions}

Biocatalysts can be used for many fermentation, reduction, decomposition, and other reactions. Biocatalyst processes are accepted widely in pharmaceutical and fine chemical synthesis. The enzymes have excellent catalytic properties and specificity. In most biological processes(enzyme-catalyzed reactions), side reactions and by-products are rarely produced. The quantity of enzymes required is very small compared to conventional catalysts. Michali Menten Kinetic equations form the basis for many investigations on enzyme kinetics. Sustainable development is becoming the goal of many investigations carried out in chemistry and chemical engineering. In many reactions, the use of biocatalyst is limited because of the organic solvent. Some of the properties of the enzyme were found to alter for better catalysis in non-aqueous solutions. Enzymes are playing a vital role in the technological developments in other agriculture-based small-scale sectors such as dairy, fishery, poultry farms, and food industries. From ancient times enzymes are used for beverage manufacturing. Investigations for improving the enzymatic processes' economy are being carried out, and novel technics are being explored.

\section{Funding}

There is no external funding involved in the preparation of this review article.

\section{Acknowledgments}

The author is thankful to the authorities of the affiliating institute for support and encouragement.

\section{Conflicts of Interest}

The authors declare no conflict of interest.

\section{References}

1. Bhatia, S. Introduction to enzymes and their applications. Introduction to Pharmaceutical Biotechnology 2018, 21-30, https://doi.org/10.1088/978-0-7503-1302-5ch1.

2. Berg, J.M.; Tymoczko J.L.; Stryer, L. Biochemistry. 5th edn. New York: Freeman, W.H. 2002.

3. Agarwal, P.K. Enzymes: an integrated view of structure, dynamics and function. Microb. Cell Fact. 2006, 5 , https://doi.org/10.1186/1475-2859-5-2.

4. Johnson, K.A.; Goody, R.S. The original Michaelis constant: translation of the Michaelis-Menten 1913 paper. Biochemistry 2011, 50, 8264-8269, https://dx.doi.org/10.1021\%2Fbi201284u.

5. Sheldon, R.A.; Woodley, J.M. Role of Biocatalysts in Sustainable Chemistry. Chem. Rev. 2018, 118, 801838, https://dx.doi.org/10.1021/acs.chemrev.7b00203.

6. Sheldon, R.A. Fundamentals of Green Chemistry: Efficiency in Reaction Design. Chem. Soc. Rev. 2012, 41, 1437-1451, https://doi.org/10.1039/C1CS15219J.

7. Sheldon, R.A. Organic Synthesis - Past, Present and Future. Chem. Ind. (London) 1992, 903-906.

8. Graedel, T.E. Chapter 4-Green chemistry and sustainable development. Handbook of Green Chemistry and Technology. Clark, J.; Macquarrie, D.J. Eds.; Blackwell Science Ltd.: Oxford, U.K., 2002, 56-61.

9. Report of the World Commission on Environment and Development: Our Common Future. Oxford University Press, Oxford, U.K., 1987.

10. Kulkarni, S.J. Bioconversion of Waste Feedstock into Useful Product: An Insight into Recent Studies and Investigations. EPRA International Journal of Research and Development 2016, 1, 98-104.

11. Kulkarni, S.J. Production of citric acid: a review on research and studies. International Journal of Advanced Research Foundation 2015, 2, 17-19.

12. Ramachandran, V.; Nisha Pujari, N.; Tanmay Matey, T.; Kulkarni, S. Enzymatic Hydrolysis for Glucose-A Review. International Journal of Science, Engineering and Technology Research 2013, 2, 1937-1942. 
13. Ramachandran, V.; Pujari, N.; Matey, T.; Kulkarni, S. Enzymatic Hydrolysis of Cassava using wheat seedlings. International Journal of Science. Engineering and Technology Research 2014, 3, 1216-1219.

14. Kulkarni, S.J. Use of Biotechnology for Synthesis of Various Products from Different Feedstocks -A Review. International Journal of Advanced Research in Bio-Technology 2014, 2, 1-3.

15. Kulkarni, S.J.; Shinde, N.L.; Goswami A.K. A Review on Ethanol Production from Agricultural Waste Raw Material. International Journal of Scientific Research in Science, Engineering and Technology 2015, 1, 231233.

16. Bekmuradov, V. Bioconversion Process of Source-Separated Organic Waste For Ethanol Production. A Dissertation Presented To Ryerson University In Partial Fulfilment of The requirements for the Degree Of Doctor Of Philosophy In The Program Of Civil Engineering 2015, 258.

17. Petre, M.; Zarnea, G.; Adrian, P.; Gheorghiu, E. Biodegradation and Bioconversion of Cellulose Wastes using Bacterial and Fungal Cells Immobilized in Radiopolymerized Hydrogels. Resources, Conservation and Recycling 1999, 27, 309-332, https://doi.org/10.1016/S0921-3449(99)00028-2.

18. Raikar, R.V. Enhanced Production Of Ethanol From Grape Waste. International Journal of Environmental Sciences 2012, 3, 776-783.

19. Wadhwa, M.; Bakshi, M.P.S. Utilization of Fruit and Vegetable Wastes as Livestock Feed and as Substrates for Generation of Other Value-Added Products. Rap Publication 2013, 67.

20. Vishwakarma, H.S.; Kumar, A.; Singh, J.; Dwivedi, S.; Kumar, M. Production of Ethanol from Fruit Wastes by using Saccharomyces Cerevisiae. International Journal Of Renewable Energy Technology Research 2014, $3,1-5$.

21. Kulkarni, S.J. Biological Reactions and their Modelling- A Brief Insight on Research and Studies. Int. J. Engg. Sc. Inv.2017, 3, 399-403.

22. Ardestani, F. Investigation of the Nutrient Uptake and Cell Growth Kinetics with Monod and Moser Models for Penicillium Brevicompactum Atcc 16024 in Batch Bioreactor. Iranica Journal Of Energy \& Environment 2011, 2, 117-121.

23. Liu, Z.; Li, X. The Kinetics of Ethanol Fermentation Based on Adsorption Processes. Kem. Ind. 2014, 63, 259-264, https://doi.org/10.15255/KUI.2013.023.

24. Van Den Wijngaard, A.; Richele, W.; Dick, J. Kinetics of Bacterial Growth on Chlorinated Aliphatic Compounds. Applied And Environmental Microbiology 1993, 59, 2041-2048, https://doi.org/10.1128/aem.59.7.2041-2048.1993.

25. Muthuvelayudham, R.; Viruthagiri, T. Fermentative Production and Kinetics of Cellulase Protein on Trichoderma Reesei using Sugarcane Bagasse and Rice Straw. Afr. J. Biotechnol 2006, 5, 1873-1881.

26. Gorak, M.; Zymanczyk-Duda, E. Application of cyanobacteria as biocatalysts for the reduction of diethyl 2oxopropylphosphonate. Chemik 2014, 68, 123-128.

27. Rodak, M.B. The Application of Fungi as Biocatalysts for the Synthesis of Optically Pure Phosphonates. Advanced Studies in Biology 2009, 1, 243-254.

28. Kaushik, N.; Biswas, S.; Singh, J. Biocatalysis and Biotransformation Processes - An Insight. The Scitech Journal 2014, 1, 15-22.

29. Kulkarni, S.J. Oxalic acid: A Review on Analysis, Syntyheis and Application. EPRA Int. J. Res. Dev. 2016, $1,17-21$.

30. Kinfe, H.H.; Chhiba, V.P.; Frederick, J.; Mathiba, K.; Brady, D. Application of stereoselective biocatalysts for the enantiomeric resolution of beta-hydroxynitriles. Journal of Biotechnology 2008, 10, https://doi.org/10.1016/j.jbiotec.2008.07.906.

31. Robertson, D.E.; Steer, B.A. Recent progress in biocatalyst discovery and optimization. Current Opinion in Chemical Biology 2004, 8, 141-149, https://doi.org/10.1016/j.cbpa.2004.02.010.

32. Kulkarni, S.J. Enzyme immobilization: research and studies. Int J Res Rev. 2016, 3, 31-35.

33. Kulkarni, S.J. Research and Studies on Vinegar Production-A Review. Int.Journal on Scientific Research In Science And Tech. 2015, 1, 146-148.

34. Nawani, N.; Singh, R.; Kaur, J. Immobilization and Stability Studies of a Lipase from Thermophilic Bacillus Sp: The Effect of Process Parameters on Immobilization of Enzyme. Electronic Journal of Biotechnology 2006, 9, 559-565.

35. Ding, L.; Yao, Z.; Li, T.; Yue, Q.; Chai, J. Study on Papain Immobilization on a Macroporous Polymer Carrier. Turk J Chem. 2003, 27, 627- 637.

36. Abdelmajeed, N.A.; Khelil O.A.; Danial, E.N. Immobilization Technology for Enhancing Bio-Products Industry. African Journal Of Biotechnology 2012, 11, 13528-13539, https://doi.org/10.5897/AJB12.547.

37. Nair, V.K.; More, M.K.; Sawant, J.J.; Thikekar, V.P.; Philip, P.A.;Ojha, M.D.; Gomase, V.S. Proteins as biocatalysts and biomaterials. International Journal of Chemical Research 2009, 1, 1-7, http://dx.doi.org/10.9735/0975-3699.1.2.1-7.

38. Adamczak, M.; Krishna, S.H. Strategies for Improving Enzymes for Efficient Biocatalysis Enzyme for Efficient Biocatalysis. Food Technol. Biotechnol. 2004, 42, 251-264.

39. Barbosaa, A.S.; Lisboaa, J.A.; Silvaa, M.A.O.; Carvalhoa, N.B.; Pereirab, M.M.; Fricksa, A.T.; Mattedid, S.; Limaa, A.S.; Franceschic, E.; Soaresa, C.M.F. The Novel Mesoporous Silica Aerogel Modified with Protic 
Ionic Liquid for Lipase Immobilization. Quim. Nova 2016, 39, 415-422, http://dx.doi.org/10.5935/01004042.20160042.

40. Osbon, Y.; Kumar, M. Biocatalysis and Strategies for Enzyme Improvement. Edited volume of Book, Biophysical Chemistry: Advanced Application edited by Khalid, M.A.A. http://dx.doi.org/10.5772/intechopen.85018.

41. Rodrigues, P.M.; David, G.F.; Ferreira, P.R.; Delatorre, A.B.; Teixeira, V.F.T.; Cubides, D.C.; Pereira, N.C.; Perez, V.H. Preparation of biocatalysts with magnetic properties: enzymatic and physical characterization seeking application in the processes assisted by magnetic fields. Rev. Mex. Fis. S 2012, 58, 112-117.

42. Neumann, G.; Cornelissen, S.; van Breukelen, F.; Hunger, S.; Lippold, H.; Loffhagen, N.; Wick, L.Y.; Heipieper, H.J. Energetics and Surface Properties of Pseudomonas putida DOT-T1E in a Two-Phase Fermentation System with 1-Decanol as Second Phase. Applied And Environmental Microbiology 2006, 72, 4232-4238, https://doi.org/10.1128/aem.02904-05.

43. Ferreira-Leitao, V.S.F.; Cammarota, M.C.; Aguieiras, E.C.G.; Vasconcelos de Sá, L.R.; Fernandez-Lafuente, R.; Freire, D.M.G. The Protagonism of Biocatalysis in Green Chemistry and Its Environmental Benefits. Catalysts 2017, 7, 1-34, http://dx.doi.org/10.3390/catal7010009.

44. Chapman, J.; Ismail, A.E.; Dinu, C.Z. Industrial Applications of Enzymes: Recent Advances, Techniques, and Outlooks. Catalysts 2018, 8, 1-26, http://dx.doi.org/10.3390/catal8060238.

45. Smith, M.R.; Khera, E.; Wen, F. Engineering Novel and Improved Biocatalysts by Cell Surface Display. Ind. Eng. Chem. Res. 2015, 54, 4021-4032. http://dx.doi.org/10.1021/ie504071f.

46. Torretta, V.; Ragazzi, M.; Trulli, E.; Feo, G.D.; Urbini, G.; Raboni, M.; Cristina Rada, E.C. Assessment of Biological Kinetics in a Conventional Municipal WWTP by Means of The Oxygen Uptake Rate Method. Sustainability 2014, 6, 1833-1847, https://doi.org/10.3390/su6041833.

47. Contois, D.E. Kinetics of Bacterial Growth: Relationship Between Population Density and Specific Growth Rate of Continuous Cultures. Gen. Microbial. 1959, 21, 40-50, https://doi.org/10.1099/00221287-21-1-40.

48. Olaoye O.S.; Kolawole O.S. Modeling of the Kinetics of Ethanol Formation from Glucose Biomass in Batch Culture with a Non-Structured Model. International Journal Of Engineering And Applications 2013, 3, 562565.

49. Rao, G.V.R.S.; Murty, K.S.; Nagendra B.D. Biokinetics of Removal of BOD and COD from Domestic Sewage using Fluidized Bed Bio-Reactor. International Journal of Engineering and Science 2015, 5, 1-6.

50. Prakash, N.B.; Sockan, V. Bio-Decomposition and Bio-Kinetic Characterization of Tannery Effluent Treatment. American International Journal Of Contemporary Research 2014, 4, 85-93.

51. Afradi, N.; Foroughifar, N.; Qomi, M.; Pasdar, H. Folic acid-supported magnetic nanoparticles as a new, highly effective heterogeneous biocatalyst for the synthesis of 3,4-dihydropyrimidine thiones and their in vitro investigation as antibacterial active agents. Biointerface Research in Applied Chemistry 2018, 8, 36613669.

52. Gawande, M.B.; Branco, P.S.; Varma, R.S. Nano-magnetite $\left(\mathrm{Fe}_{3} \mathrm{O}_{4}\right)$ as a support for recyclable catalysts in the development of sustainable methodologies. Chemical Society Reviews 2013, 42, 3371-3393, https://doi.org/10.1039/C3CS35480F.

53. Gawande M.B.; Bonifácio V.D.;Varma R.S.; Nogueira I.D.; Bundaleski N.; Ghumman C.A.A.; Teodor O.M.; Branco P.S. Magnetically recyclable magnetite-ceria (Nanocat-Fe-Ce) nanocatalyst- applications in multicomponent reactions under benign conditions. Green Chemistry 2013, 15, 1226-1231, https://doi.org/10.1039/C3GC40375K.

54. Husain, Q. An overview on the green synthesis of nanoparticles and other nanomaterials using enzymes and their potential applications. Biointerface Research in Applied Chemistry 2019, 9, 4255-4271, https://doi.org/10.33263/BRIAC95.255271.

55. Schneidewind, H.; Schüler, T.; Strelau, K.K.; Weber, K.; Cialla, D.; Diegel, M.; Mattheis, R.; Berger, A.; Möller, R.; Popp, J. The morphology of silver nanoparticles prepared by enzymeinduced reduction. Beilstein J. Nanotechnol. 2012, 3, 404-414, https://doi.org/10.3762/bjnano.3.47.

56. Iravani, S.; Korbekandi, H.; Mirmohammadi, S.V.; Zolfaghari1, B. Synthesis of silver nanoparticles: chemical, physical and biological methods. Res. Pharm. Sci. 2014, 9, 385-406.

57. Kacar, D.; Baltaci, A.K.; Ayar, A.; Mogulkoc, R. Examination of the effects of different phosphodiesterase type 5 enzyme inhibitors on the isolated rat myometrium contraction. Biointerface Research in Applied Chemistry 2018, 8, 3237-3240.

58. Ayar A.; Tocolytic effect of parecoxib, A new parenteral cyclooxygenase-2-specific inhibitor on the spontaneous and prostaglandininduced contractions of rat isolatedmyometrium. Clinical and Experimental Pharmacology and Physiolology 2007, 737-441.

59. Nagiub, M.; Filippone, S.; Durrant, D.; Das, A.; Kukreja, R.C. Long acting PDE5 inhibitor tadalafil prevents early doxorubicin-induced left ventricle diastolic dysfunction in juvenile mice: potential role of cytoskeletal proteins. Canadian Journal of Physiology and Pharmacology 2017, 295-304, https://doi.org/10.1139/cjpp2016-0551.

60. Lauro, F.V.; Francisco, D.C.; Marcela, R.N.; Virginia, M.A.; Patricia, H.V.; Laura, B.C.; Pool Gómez, E.; Lenin, H.H.; Maria, L.R.; Regina, C.C.; Tomas, L.G.; Yaritza, B.B.; Jhair, C.T.; Maria, G.M. Synthesis and theoretical activity of three steroid-derivatives on both aromatase and 17 $\beta$-hydroxysteroid dehydrogenase 
type 1 enzymes. Biointerface Research in Applied Chemistry 2019, 9, 3898-3906, https://doi.org/10.33263/BRIAC92.898906.

61. Rosas-Nexticapa, M.; Figueroa-Valverde, L.; Cedillo, F.D.; Camacho-Luis, A.; Mateu-Armand, V.; HerreraMeza, S.; García-Cervera, E.; Gómez, E.P.; Lopez-Ramos, M.; Hau-Heredia, L.; Estrella-Barron, R.; Alfonso-Jimenez, A.; Cabrera-Tuz, J.; Noh-Delgado, R.; Mari-Parra, A. Preparation of five estrone analogs and theoretical analysis of its interaction with aromatase enzyme. Biointerface Research in Applied Chemistry 2018, 8, 3644-3651.

62. Dua, A. Enzyme Kinetics at the Molecular Level. Resonance 2019, 24, 297-311, https://doi.org/10.1007/s12045-019-0781-9.

63. Legodi, L.M.; La Grange, D.; Rensburg E.L.J.; Ncube, I. Isolation of Cellulose Degrading Fungi from Decaying Banana Pseudostem and Strelitzia alba. Hindawi Enzyme Research 2019, 2019, 1-10, https://doi.org/10.1155/2019/1390890.

64. Zhuang, J.; Marchant, M.A.; Nokes, S.E.; Strobel, H.J. Economic analysis of cellulase production methods for bioethanol. Applied Engineering in Agriculture 2007, 23, 679-687.

65. Touijer, H.; Benchemsi, N.; Ettayebi, M.; Idrissi, A.J.; Chaouni, B.; Bekkari, H. Thermostable Cellulases from the Yeast Trichosporon sp. Hindawi Enzyme Research 2019, 2019, 1-6, https://doi.org/10.1155/2019/2790414.

66. Xu, Z; Cen, Y; Zou, S; Xue, Y; Zheng, Y. Recent advances in the improvement of enzyme thermostability by structure modification. Crit Rev Biotechnol. 2020, 40, 83-98, https://doi.org/10.1080/07388551.2019.1682963.

67. Megha, S.V.; Maragathavalli, S.; Brindha, S.; Karthikeyan, V.; Annadurai, B.; Gangwar, S.K. Isolation and Purification of Cellulase. Int.j Sci. Nat. 2015, 6 , 474-479.

68. Prast-Nielsen, S.; Huang, H.H.; Williams, D.L. Tioredoxin glutathione reductase: Its role in redox biology and potential as a target for drugs against neglected diseases. Biochimica et Biophysica Acta (BBA) - General Subjects 2011, 1810, 1262-1271, https://doi.org/10.1016/j.bbagen.2011.06.024.

69. Agorio, A.; Chalar, C.; Cardozo, S.; Salinas, G. Alternative mRNAs arising from trans-splicing code for mitochondrial and cytosolic variants of Echinococcus granulosus thioredoxin glutathione reductase. Te Journal of Biological Chemistry 2003, 278, 12920-12928, https://doi.org/10.1074/jbc.m209266200.

70. Rendon, J.L.; Miranda-Leyva, M.M. Insight into the Mechanistic Basis of the Hysteretic-Like Kinetic Behavior of Thioredoxin-Glutathione Reductase (TGR). Hindawi Enzyme Research 2018, 17, https://doi.org/10.1155/2018/3215462.

71. Roy, K.; Dey, S.; Uddin, M.K.; Barua, R.; Hossain, M.T. Extracellular Pectinase from a Novel Bacterium Chryseobacterium indologenes Strain SD and Its Application in Fruit Juice Clarification. Hindawi Enzyme Research 2018, 2018, https://doi.org/10.1155/2018/3859752.

72. Satapathy, S.; Rout, J.R.; George Kerry, G.; Thatoi, H.; Sahoo, S.L. Biochemical Prospects of Various Microbial Pectinase and Pectin: An Approachable Concept in Pharmaceutical Bioprocessing. Front. Nutr.2020, https://doi.org/10.3389/fnut.2020.00117.

73. Nigam, P.S. Microbial enzymes with special characteristics for biotechnological applications. Biomolecules 2013, 3, 597-611, https://doi.org/10.3390/biom3030597.

74. Wilkowska, A; Nowak, A; Antczak-Chrobot, A; Motyl, I; Czyzowska, A; Paliwoda, A. Structurally different pectic oligosaccharides produced from apple pomace and their biological activity in vitro. Foods. 2019, 8, https://doi.org/10.3390/foods8090365.

75. Ikarashi, N.; Sato, W.; Toda, T.; Ishii, M.; Ochiai, W.; Sugiyama, K. Inhibitory effect of polyphenol-rich fraction from the bark of Acacia mearnsii on itching associated with allergic dermatitis. Evidence-Based Complementary and Alternative Medicine 2012, 2012, https://doi.org/10.1155/2012/120389.

76. Kato, C.G.; Gonçalves, G.D.A.; Peralta, R.A.; Seixas, F.A.V.; Sá-Nakanishi, A.B. ; Bracht, L.; Comar, J.F.; Bracht, A.; Peralta, R.M. Inhibition of $\alpha$-Amylases by Condensed and Hydrolysable Tannins: Focus on Kinetics and Hypoglycemic Actions. Hindawi Enzyme Research 2017, 2017, https://doi.org/10.1155/2017/5724902.

77. Kumari, N.; Sushil, Rani, B.; Malik K.; Avtar, R. Microbial amylases: An overview on recent advancement. Journal of Entomology and Zoology Studies 2019, 7, 198-205.

78. Martina, M.F.; Okpob, E.A.; Andyc, I.E. Microbial amylases: A review. World News of Natural Sciences 2019, 22, 174-179.

79. Liangliang, J.; Zhifen, P.; Haili Zhang H.; Qiao L.; Junjun, L.; Guangbing, D.; Maoqun,Y.; Hai, L. New insights into the origin and evolution of $\alpha$-amylase genes in green plants. Scientific Reports 2019, 9, https://doi.org/10.1038/s41598-019-41420-w.

80. Bhattacharjee, I.; Mazumdar, D.; Saha, S.P. Microbial amylases and their potential application in industries: A review. The Pharma Innovation Journal 2019, 8, 162-170.

81. Timson, D.J. Four Challenges for Better Biocatalysts. Fermentation 2019, 5, https://doi.org/10.3390/fermentation5020039.

82. Yang, Y.; Zhang, J.; Wu, D.; Xing, Z.; Zhou, Y.; Shi, W.; Li, Q. Chemoenzymatic synthesis of polymeric materials using lipases as catalysts: A review. Biotechnol. Adv. 2014, 32, 642-651, https://doi.org/10.1016/j.biotechadv.2014.04.011. 
83. Kumar, A.; Dhar, K.; Kanwar, S.S.; Arora, P.K. Lipase catalysis in organic solvents: Advantages and applications. Biol. Proced. Online 2016, 18, https://doi.org/10.1186/s12575-016-0033-2.

84. Zhang, M.M.; Su,X.; Ang, E.L.; Zhao, H. Recent advances in biocatalyst development in the pharmaceutical industry. Pharm. Bioprocess. 2013, 1, 179-196.

85. Lee, J.; Kim, J.; Kim, H.; Kim, E.J.; Jeong, H.; Choi, K.; Kim, B. Characterization of a Tryptophan 6Halogenase from Streptomyces albus and Its Regioselectivity Determinants. Chembiochem 2020, 21, 44464452, https://doi.org/10.1002/cbic.201900723.

86. Bashir, N.; Sood, M.; Bandral, J. Enzyme immobilization and its applications in food processing: A review. International Journal of Chemical Studies 2020,261 , https://doi.org/10.22271/chemi.2020.v8.i2d.8779.

87. Labus, K.; Wolanin, K.; Radosinski, L. Comparative Study on Enzyme Immobilization Using Natural Hydrogel Matrices_Experimental Studies Supported by Molecular Models Analysis. Catalysts 2020, 10, https://doi.org/10.3390/catal10050489.

88. Chou, C.; Syu, S.; Chang, J.H.; Aimar, P.; Chang, Y. Bioinspired Pseudozwitterionic Hydrogels with Bioactive Enzyme Immobilization via pH-Responsive Regulation. Langmuir 2019, 35, 1909-1918, https://doi.org/10.1021/acs.langmuir.8b02483.

89. Bao, Z.; Xian, C.; Yuan, Q.; Liu, G.; Wu, J. Natural Polymer-Based Hydrogels with Enhanced Mechanical Performances: Preparation, Structure, and Property. Adv. Healthc. Mater. 2019, 8, https://doi.org/10.1002/adhm.201900670.

90. Basso, A.; Serban, S. Industrial applications of immobilized enzymes-A review. Mol. Catal. 2019, 479, https://doi.org/10.1016/j.mcat.2019.110607.

91. Bilal, M.; Zhao, Y.; Noreen, S.; Shah, S.Z.H.; Bharagava, R.N.; Iqbal, H.M.N. Modifying bio-catalytic properties of enzymes for efficient biocatalysis: A review from immobilization strategies viewpoint. Biocatal. Biotransform. 2019, 37, 159-182, https://doi.org/10.1080/10242422.2018.1564744.

92. Liu, Q.; Xun, G.; Feng, Y. The state-of-the-art strategies of protein engineering for enzyme stabilization. Biotechnol. Adv. 2019, 37, 530-537, https://doi.org/10.1016/j.biotechadv.2018.10.011.

93. Raveendran, S.; Parameswaran,B.; Ummalyma,S.B.; Abraham, A,; Mathew, A.K.; Madhavan, A,; Rebello, A.; Pandey, A. Applications of Microbial Enzymes in Food Industry. Food Technol Biotechnol. 2018, 56, 16-30, https://doi.org/10.17113/ftb.56.01.18.5491.

94. Rodríguez Couto S.; Ángeles Sanroman M. Application of solid-state fermentation to food industry - A review. J Food Eng. 2006, 76, 291-302, https://doi.org/10.1016/j.jfoodeng.2005.05.022.

95. Aiyer, P.V. Amylases and their applications. Afr J Biotechnol. 2005, 4, 1525-9.

96. Blanco, C.A.; Caballero, I; Barrios, R; Rojas A. Innovations in the brewing industry: Light beer. Int J Food Sci Nutr. 2014, 65, 655-60, https://doi.org/10.3109/09637486.2014.893285.

97. Tucker, G.A.;Woods, L.F.J. Enzymes in food processing. Boston, MA, USA: Springer; 1995; https://doi.org/10.1007/978-1-4615-2147-1.

98. Yuvaraj, M.; Ramasamy, M. Role of Fungi in Agriculture. The Edited Volume Bio stimulants in Plant Science. Edited Mirmajlessi, S.M.; Radhakrishnan, R. 2019, https://doi.org/10.5772/intechopen.89718.

99. Gunjal, A.B.; Waghmode, M.S.; Patil, N.N.; Nawani, N.N. Chapter 9 - Significance of soil enzymes in agriculture. In: Smart Bioremediation Technologies. Bhatt, P. Ed. Academic Press: 2019; 159-168, https://doi.org/10.1016/B978-0-12-818307-6.00009-3.

100.Rozylol, K.; Bohacz, J. Microbial and enzyme analysis of soil after the agricultural utilization of biogas digestate and mineral mining waste. International Journal of Environmental Science and Technology 2020, 17, 1051-1062, https://doi.org/10.1007/s13762-019-02522-0.

101.Holik, L.; Hlisnikovsky, L.; Honzík, R.; Trogl, J.; Hana .B.; Popelka, J. Soil Microbial Communities and Enzyme Activities after Long-Term Application of Inorganic and Organic Fertilizers at Different Depths of the Soil Profile. Sustainability 2019, 11, https://doi.org/10.3390/su11123251.

102. Catherine T.; Tony S. The Second Domestication of Plants and Animals, the Disruption of the Cow, and the Collapse of Industrial Livestock Farming. Rethinking Food and Agriculture 2020-2030 2019, 75.

103. Cezary A.K.; Elzbieta H.; Feledyn-Szewczyk, B.; Antonkiewicz, J. Enzymatic Activity of Loess Soil in Organic and Conventional Farming Systems. Agriculture 2020, 10, 1-14, https://doi.org/10.3390/agriculture10040135.

104.Grigore-Gurgu, L.; Bucur, F.I.; Borda, D.; Alexa, E.; Neagu, C.; Nicolau, A. Biofilms Formed by Pathogens in Food and Food Processing Environments. In: Bacterial Biofilms. Edited by Sadik, D.; Melis, S.Ö.; Afet, A. 2020; https://doi.org/10.5772/intechopen.90176.

105.Costa-Silva, T.A; Flores-Santos, J.C.; Freire, R.K.B.; Michele Vitolo, M.; Pessoa-Jr, A. Microbial cell disruption methods for efficient release of enzyme L-asparaginase. Preparative Biochemistry and Biotechnology 2018, 48, 707-717, https://doi.org/10.1080/10826068.2018.1487850.

106.Pirich, C.L.; Picheth, G.L.; Fontes, A.M.; Delgado-Aguilar, M.; Ramos, L.P. Disruptive enzyme-based strategies to isolate nanocelluloses: a review. Cellulose 2020, 27, 5457-5475, https://doi.org/10.1007/s10570020-03185-8. 
107. Aissa, K; Karaaslan, M.A.; Renneckar, S.; Saddler, J.N. Functionalizing cellulose nanocrystal with Click modifiable carbohydrate-binding modules. Biomacromol 2019, 20, 3087-3093, https://doi.org/10.1021/acs.biomac.9b00646.

108. Barruetabena, N.; Alonso-Lerma, B.; Galera-Prat, A.; Joudeh, N.; Barandiaran, L.; Aldazabal, L.; Arbulu, M.; Alcalde, M.; De Sancho D.; Gavira. J.A. Resurrection of efficient Precambrian endoglucanases for lignocellulosic biomass hydrolysis. Commun Chem 2019, 2, https://doi.org/10.1038/s42004-019-0176-6.

109.Balea, A.; Blanco, A.; Negro, C. Nanocelluloses: natural based materials for fiber-reinforced cement composites. Polymers 2019, 11, https://doi.org/10.3390/polym11030518.

110. Bernardes, A.; Pellegrini, V.; Curtolo, F.; Camilo, C.; Mello, B.; Johns, M.; Scott, J.; Guimaraes, F.; Polikarpov, I. Carbohydrate binding modules enhance cellulose enzymatic hydrolysis by increasing access of cellulases to the substrate. Carbohyd Polym 2019, 211, 57-68, https://doi.org/10.1016/j.carbpol.2019.01.108.

111. Mir Khan, U.; Selamoglu, Z. Use of Enzymes in Dairy Industry: A Review of Current Progress. Archives of Razi Institute 2020, 75,131-136, https://doi.org/10.22092/ari.2019.126286.1341.

112.Dekker, P.J.T.; Koenders, D.; Bruins, M.J.; Lactose-Free Dairy Products: Market Developments, Production, Nutrition and Health Benefits. Nutrients 2019, 11, https://doi.org/10.3390/nu11030551.

113. Bezie, A.; Regasa, H. The Role of Starter Culture and Enzymes/ Rennet for Fermented Dairy Products Manufacture- A Review. Nutri Food Sci Int J 2019, 9, 21-28.

114. Attia, Y.A. The Use of Enzymes in Poultry Diets trends and Approaches, A Minimum Review. Acta Scientific Nutritional Health 2019, 3, 95-97.

115.Selim, N.A.; Magied, H.A.A.; Habib, H.H.; Waly, A.H.; Fadl, A.A.; Shalash, S.M. Using Protease and Xylanase Enzymes as Single or Combined Supplementation to Corn-Soybean Meal Broiler Diets. EC Veterinary Science 2019, 4, 637-652.

116.Barisic, V.; Kopjar, M.; Jozinovic , A.; Flanjak, I.; Ackar, D.; Milicevic, B.; Subaric, D.; Jokic, S.; Babic, J. The Chemistry behind Chocolate Production. Molecules 2019, 24, https://doi.org/10.3390/molecules24173163.

117. Urbanska, B.; Derewiaka, D.; Lenart, A.; Kowalska, J. Changes in the composition and content of polyphenols in chocolate resulting from pre-treatment method of cocoa beans and technological process. European Food Research and Technology 2019, 245, 2101-2112, https://doi.org/10.1007/s00217-01903333-w.

118. de Brito, E.S.; García, N.H.P.; Amancio, A.C. Use of a Proteolytic Enzyme in Cocoa (Theobroma cacao L.) Processing. Brazilian Archives of Biology and Technology 2004, 47, 553-558, http://dx.doi.org/10.1590/S1516-89132004000400008.

119. Vitolo, M. Calcium-alginate beads as carriers for biocatalyst encapsulation. World Journal of Pharmaceutical Research 2019, 8.

120. Sibel Uzuner, S.; Deniz Cekmecelioglu, D.; Chapter 3 - Enzymes in the Beverage Industry. In: Enzymes in Food Biotechnology. Editor(s): Mohammed, K. Academic Press, 2019; 29-43, https://doi.org/10.1016/B9780-12-813280-7.00003-7.

121. Vitolo, M. Enzymes in the Production of Juices and Beverages. World Journal of Pharmacy And Pharmaceutical Sciences 2020, 9, 504-517.

122. Ogasawara, M.; Yoshii, K.; Wada, J.; Yamamoto, Y.; Inouye, K. Identification of guanine, guanosine, and inosine for $\alpha$-amylase inhibitors in the extracts of the earthworm Eisenia fetida and characterization of their inhibitory activities against porcine pancreatic $\alpha$-amylase. Enzyme and Microbial Technology 2020, 142, https://doi.org/10.1016/j.enzmictec.2020.109693.

123.Dogan, S.; Ozcan, T.; Dogan, M.; Turhan, Y. The effects on antioxidant enzymes of PMMA/hydroxyapatite nanocomposites/composites. Enzyme and Microbial Technology 2020, 142, https://doi.org/10.1016/j.enzmictec.2020.109676.

124.Jeandet, P.; Sobarzo-Sánchez, E.; Silva, A.S.S.; Clément, C.; Nabavi, A.F; Battino, M.; Rasekhian, M.; Belwal, T.; Habtemariam, S.; Koffas, M.; Nabavi, S.M. Whole-cell biocatalytic, enzymatic and green chemistry methods for the production of resveratrol and its derivatives. Biotechnology Advances 2020, 39, https://doi.org/10.1016/j.biotechadv.2019.107461. 